\title{
ОСОБЛИВОСТІ ІНФОРМАЦІЙНО-УПРАВЛЯЮЧИХ СИСТЕМ ЛОГІСТИКИ В РОЗРІЗІ ЇХ ПІДСИСТЕМ
}

\author{
Криворучко О. В. \\ д. т. н., професор, завідувач кафедри програмної інженерї та інформачійних систем \\ Київського торговельно-економічного університету, Україна
}

Десятко А. М.

ст. викладач кафедри програмної інженерії та інформаційних систем

Київського торговельно-економічного університету, Україна

DOI: https://doi.org/10.31435/rsglobal_ws/12072018/6005

\section{ARTICLE INFO}

Received: 16 May 2018

Accepted: 21 June 2018

Published: 12 July 2018

\section{KEYWORDS}

information and management systems;

information systems;

logistics;

information logistics;

logistics information system

\begin{abstract}
The place of information management system`s subsystems of trade organizations logistics in the enterprise information system is considered here. Particular attention is paid to the description of subsystems and the definition of their functional characteristics when a single structured information management system of the enterprise is creating. And also the tasks of each subsystem are defined in the context of the general information management system. A hypothesis is suggested that information and management systems relating to the various groups are integrated into a single information space based on vertical and horizontal integration. The needs for secured software products that satisfy the needs during the construction of logistics information systems are searched here The technical advantages and opportunities are determined with the continuous and efficient construction of logistic processes.
\end{abstract}

Citation: Криворучко О. В., Десятко А. М. (2018) Osoblyvosti Informatsiino-Upravliaiuchykh System Lohistyky v Rozrizi Yikh Pidsystem. World Science. 7(35), Vol.2. doi: 10.31435/rsglobal_ws/12072018/6005

Copyright: (C) 2018 Криворучко О. В., Десятко А. М. This is an open-access article distributed under the terms of the Creative Commons Attribution License (CC BY). The use, distribution or reproduction in other forums is permitted, provided the original author(s) or licensor are credited and that the original publication in this journal is cited, in accordance with accepted academic practice. No use, distribution or reproduction is permitted which does not comply with these terms.

Вступ. Загальна мета логістики, як відомо, зводиться до створенням ефективної системи управління матеріальними, фінансовими, інформаційними, сервісними та іншими потоками. У той же час концептуальна ідея логістики - досягнення з найменшими можливими в даних умовах витратами найбільжої пристосованості підприємства до мінливої ринкової середовищі, розширення масштабів ринкової присутності і отримання переваг перед конкурентами [5]. На сьогодні, логістика в всьому світі є дуже важливим інструментом, який визначає стратегію збуту товарів на макро- та мікрорівнях в будь-якій країні, можна сказати, що визначає стратегічний напрям в сфері торгівлі. Успіх досягається насамперед за рахунок того, що товаровиробники повинні швидко змінюватися та адаптуватися до динамічних умов ринкового середовища. При цьому головною вимогою стало максимальне скорочення всіх тимчасових стадій життєвого (логістичного) циклу продукції а саме: термінів проведення науково-дослідних і дослідноконструкторських робіт, часу поставок сировини і матеріалів, тривалості виробничого циклу, термінів обробки замовлень, доставки і реалізації продукції Ґ2].

Особливості інформаційно-управляючих систем різних видів в розрізі їх функціональних підсистем має не аби яке значення в такому сегменті як логістика. 
Результати досліджень. Інформаційно-управляючі системи логістики торгових підприємств характеризуються: функціональними підсистемами, а також підсистемами, що відповідають за їх ефективну та безперебійну роботу.

Функціональні підсистеми характеризуються завданнями, які потрібно вирішувати, а підсистеми, що направлені на забезпечення роботи характеризуються наступними елементами: технічними, інформаційними і математичними.

Інформаційно-управляючі системи логістики торгового підприємства можна поділити на три групи [1]:

1. Планові

2. Диспозитивні

3. Виконавчі

Планові інформаційні системи (ПІС) призначені для прийняття довгострокових рішень, що мають стратегічний характер та притаманні верхньому рівню управління. Ми можемо виділити наступні завдання, що характеризують ПІС:

- створення, удосконалення, оптимізація частин логістичного ланцюга;

- управління умовно-постійними даними;

- планування виробництвом, збутом, запасами, ресурсами;

- загальне управління виробництвом, збутом, запасами, ресурсами;

- управління резервами та іншими оперативними завданнями.

Диспозитивні інформаційні системи створюються на рівні управління складом або виробничим цехом і призначені для забезпечення налагодженої роботи логістичних систем. За допомогою даних систем вирішуватися такі завдання, як:

- детальне, ціленаправлене управління запасами, ресурсами та накопичення їх (за потребою);

- регулювання транспортних засобів, що відносяться до даного рівня управління ;

- відбір, сортування, комплектація та пакування вантажів за замовленням;

- облік руху товарів;

- інші оперативні завдання.

Виконавчі інформаційні системи створюються для забезпечення адміністративного та оперативного управління підприємством торгівлі, складом. Обробка інформації в цих системах проводиться в режимі реального часу та напряму залежить від людино-машинної взаємодії. Темп обробки інформації обумовлений:

- швидкістю надходження даних про рух товарів;

- наявністю спеціалізованого програмного забезпечення;

- існування сучасних технічних засобів (РС),

- присутність кваліфікованих працівників.

Щоб мати можливість впливати як на адміністративному, так і на управляючому рівні на об'єкт управління та отримувати необхідну інформацію про рух товарів у поточний момент, важливо підтримувати режим роботи «у реальному часі».

Вище наведеними системами можуть вирішуватися різні завдання:

- контроль матеріальних, інформаційних, фінансових та ін. потоків;

- управління виробництвом, збутом, запасами, ресурсами;

- оперативне та адміністративне управління;

- облік руху товарів і т.д.

Інформаційно-управляючі системи в логістиці можуть створюватися з метою управління матеріальними, інформаційними, фінансовими та ін. потоками на рівні окремого підприємства (на мікрорівні). Також інформаційно-управляючі системи можуть сприяти організації логістичних процесів на обласному рівні, в межах окремої країни та на рівні торговоекономічного (політичного) об’єднання групи країн (на макрорівні) (рис.1). 


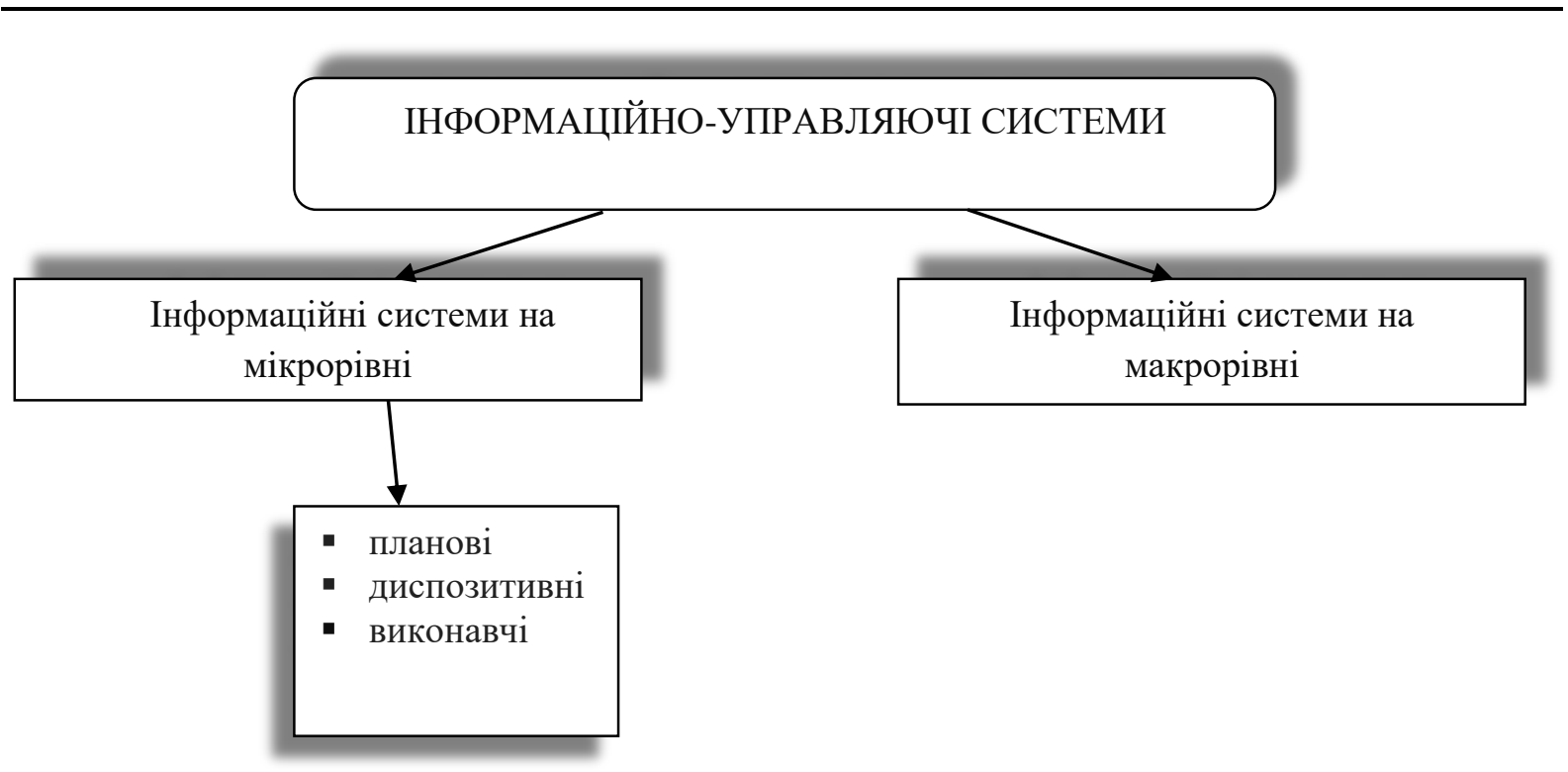

Рис.1. Схематичне представлення розділення інформачійно-управляючих систем на мікро- та макрорівнях

Слід зазначити, що будь-яка логістична система є динамічною. Щоб мати можливість ефективно управляти нею, необхідно в будь-який момент мати доступ до всіх логістичних потоків, що циркулюють на підприємстві вцілому та розподіляти їх відносно вище наведених груп (планових, диспозитивних, виконавчих). Поставлене завдання вирішується шляхом правильно створеної інформаційно-управляючої системи, яка складається з надійних підсистем, має достатнє сучасне технічне забезпечення, та кваліфікований людський ресурс. Наприклад, одним з нововведень на підприємствах, які прагнуть оптимізувати роботу є використання QRкодів. Йдеться про обладнання, яке здатне сканувати (зчитувати) двовимірні коди. При цьому, $\epsilon$ можливість обробляти більшу кількість інформації за одиницю часу, що дозволяє інформаційноуправляючій системі реагувати на неї в оптимальні терміни [5]. Сучасні торговельні компанії можуть мати велику кількість контрагентів, з чого випливає потреба в ефективній логістичній діяльності. Використання сучасного технічного обладнання та програмного продукту, заснованого на скануванні кодів, проявляється в безпомилковому визначенні який товар, в якій кількості, куди і коли треба доставити і за якою ціною продати, щоб це принесло прибуток.

В сучасних умовах управління логістичними процесами широко застосовують радіочастотні мітки, які є довговічними, зчитуються на відстані, їх можна доповнювати, заносити в них велику кількість даних, розташовувати де завгодно, крім того, на них не впливає бруд і пил 「1].

Але так чи інакше постає питання яка ж користь від інформаційно-управляючих систем логістики при управління потоками? Цей аспект розглядаємо по трьом напрямках (таб 1).

Таблиця 1. Інформаційно-управляюча система логістики при управлінні потоками [2]

\begin{tabular}{|c|c|c|}
\hline На виробництві & На складі & В торгівлі \\
\hline $\begin{array}{l}\text { - створення єдиної системи } \\
\text { обліку та контролю за рухом } \\
\text { виробів на кожній ділянці; } \\
\text { • скорочення чисельності } \\
\text { допоміжного персоналу та } \\
\text { звітної документації, } \\
\text { виключення помилок. }\end{array}$ & $\begin{array}{l}\text { • } \quad \text { автоматизація обліку і } \\
\text { контролю за рухом } \\
\text { матеріального потоку; } \\
\text { • автоматизація процесу } \\
\text { інвентаризації матеріальних } \\
\text { запасів; } \\
\text { • скорочення часу на } \\
\text { логістичні операції } 3 \\
\text { матеріальним і } \\
\text { інформаційним потоками. }\end{array}$ & $\begin{array}{l}\text { • створення єдиної системи } \\
\text { обліку матеріального потоку; } \\
\text { • автоматизація замовлення } \\
\text { і інвентаризації замовлення; } \\
\text { скорочення часу } \\
\text { обслуговування покупців. }\end{array}$ \\
\hline
\end{tabular}

В сучасних умовах створюються велика кількість прикладних програм, для забезпечення існування інформаційно-управляючої системи логістики торговельного підприємства. Однак 
застосовати їх повсюдно не є раціональним без аналізу потреб інформаційних систем. На даному етапі важко говорити про уніфікацію чи стандартизацію потреб в ПЗ.

У диспозитивних інформаційних системах можливість застосовувати стандартний пакет програм знижується. Адже, всі виробничі процеси на підприємствах складаються роками та важко піддаються змінам задля уніфікації; кожне окреме підприємство має різну структуру даних, що обробляється та істотно може відрізнятися як на однотипних підприємствах в межах однієї країни чи групи країн.

У виконавчих інформаційних системах на оперативному рівні управління, заради швидкого відгуку застосовують програмне забезпечення, яке є унікальним та оригінальним.

Відповідно до концепції логістики інформаційно-управляючі системи, що відносяться до різних груп, інтегруються в єдину інформаційний простір на основі вертикальної та горизонтальної інтеграції [5]. Якщо використовуються вертикальні інформаційні потоки при зв'язку між плановою, диспозитивною і виконавчою системами, то ми говоримо про вертикальну інтеграцію. А коли зв'язок формується за допомогою горизонтальних інформаційних потоків між окремими комплексами завдань у диспозитивних і виконавчих системах, то це $\epsilon$ горизонтальна інтеграція.

В цілому переваги інформаційно-інтегрованих систем полягає в тому, що зростає швидкість обміну інформацією, зменшується кількість помилок в обліку та зменшується обсяг непродуктивної «паперової» роботи, що оптимізує функціонування загальної інформаційноуправляючої системи підприємства.

Висновки. Створення багаторівневих інформаційно-управляючих систем пов'язане зі значними витратами, в основному в області розробки програмного забезпечення, яке, з одного боку, має бути направлене багатофункціональність системи, а з іншого мати високий ступінь їі інтеграції та забезпечувати роботу всіх підсистем та рівнів.

У зв'язку 3 цим, оскільки інформаційно-управляючі системи в логістиці характеризуються як своїми функціональними підсистемами, так i підсистемами, які забезпечують їх безперебійну та ефективну роботу, то потрібно досліджувати можливість використання порівняно недорогого стандартного програмного забезпечення, 3 його адаптацією до місцевих вимог.

\section{ЛІТЕРАТУРА}

1. Бушуєв С.Д. Моделі і методи управління проектами: Навчальний посібник/ С.Д. Бушуєв, С.В. Цюцюра, О.В. Криворучко та ін. - К.: КНУБА, 2016. - 196 с

2. Гура, Н. О. Неприбуткові організації в Україні: особливості діяльності та класифікація [Текст] / Н. О. Гура // Економіка України. - 2012. - № 8. - С. 23-31

3. Фадеев, В. Некоммерческие организации в Беларуси: статус, проблемы, перспективы [Электронный pecypc] / В. Фадеев // Юридический мир. - 2011. - №2. - Режим доступа: http:// www.profmedia.by/pub/bnp/art/51106/.

4. Криворучко О.В. Методи проекцій об'єктних моделей на структури даних [Текст] / М.І. Цюцюра, О.В. Криворучко // Управління розвитком складних систем. - 2015. - № 21. - С. 99 -105.

5. Криворучко О.В. Зарубіжна практика застосування основних логістичних концепцій і систем / О. В. Криворучко, М. І. Цюцюра, А. М. Десятко // Розвиток освіти, науки, економіки в умовах інтеграційних процесів : матеріали Всеукр. наук.-практ. конф., 20 квітня 2017 р., Вінниця / М-во освіти і науки України, ВНHIЕ ТНЕУ. - Тернопіль: Крок, 2017. - Т. 1, ч. 1. - С. 92-94 